\title{
Strategies of China's Maritime Actors in the South China Sea
}

A Coordinated Plan under the Leadership of Xi Jinping?

\section{Shinji Yamaguchi}

\section{(2) OpenEdition}

\section{Journals}

Electronic version

URL: http://journals.openedition.org/chinaperspectives/7022

DOI: 10.4000/chinaperspectives.7022

ISSN: 1996-4617

\section{Publisher}

Centre d'étude français sur la Chine contemporaine

Printed version

Date of publication: 1 September 2016

Number of pages: 23-31

ISSN: 2070-3449

\section{Electronic reference}

Shinji Yamaguchi, «Strategies of China's Maritime Actors in the South China Sea », China Perspectives [Online], 2016/3 | 2016, Online since 01 September 2017, connection on 28 October 2019. URL : http:// journals.openedition.org/chinaperspectives/7022 ; DOI : 10.4000/chinaperspectives.7022

(c) All rights reserved 


\title{
Strategies of China's Maritime
}

\section{Actors in the South China Sea}

\author{
A Coordinated Plan under the Leadership of Xi Jinping?
}

\author{
SHIN川 YAMAGUCHI
}

\begin{abstract}
This paper aims to explore the coordination among China's various maritime actors in the South China Sea (SCS). Since around 2009, China has reinforced its maritime territorial claims in the SCS and has taken coercive measures, including harassing other countries' vessels and using administrative tools to expand its effective control over disputed islands. One important question is whether China's tactics are based on a well-coordinated plan or are the unintended consequence of competition and self-interest among the various agencies. This paper shows that, firstly, organisational coordination between these agencies is improving, secondly, that the PLA has a salient role in the operation, and lastly, that the long-term trend is important. The paper implies that long-term aspirations are coalescing into more concrete plans under the strong leadership of Xi Jinping.
\end{abstract}

KEYWORDS: China, Xi Jinping, South China Sea, land reclamation, maritime disputes, oil rig, PLA, Maritime Militia.

\section{Introduction (1)}

S ince around 2009, China has reinforced its maritime territorial claims in the South China Sea (SCS) and has tried to deter other states from strengthening their claims at China's expense. China has employed a range of diplomatic, administrative, economic, and military tactics to expand its effective control over disputed territories. (2)

Are China's tactics based on a well-coordinated plan, or are they the unintended consequence of competition and self-interest among various agencies? Do China's maritime actors compete for their own narrow interests to an extent that could disrupt China's overall strategy? Or are these actors working under the broad policy direction of the Chinese Communist Party (CCP)? Also, what is the role of the People's Liberation Army (PLA) in the SCS? These are questions that this paper will try to answer.

There are two views on the questions. In one of her recent papers published in 2014, Linda Jakobson argues that China's actions in the maritime domain take place unsystematically and organically rather than as part of a grand strategy. Various actors cooperate when it serves both parties' interests, and "there is no evidence of a central government approved grand plan that mandates different actors coercing other claimants in a tailored way." (3) On the other hand, Bonnie Glaser argues that China's various maritime actors are increasingly coordinated and directed by senior policymakers as part of a larger strategy aimed at protecting China's sovereignty and maritime rights. (4)

This paper argues that although coordination problems did exist in the Hu Jintao era, as detailed in Jakobson's works, coordination among maritime actors has been improving, especially under the Xi Jinping administration. Of course, this is not to say that $X i$ linping has overcome all of the problems in China's political system at once, but the development of coordination is an important trend deserving further exploration.
The questions are part of a broader debate on China's political system. Since the 1990s, China's political system has been frequently referred to as "fragmented authoritarianism" in which authority at the very peak of the Chinese political system is centralised, but the layers below it are fragmented and disjoined. (5)

1. The views expressed in this paper are those of the author alone and do not necessarily reflect the policies of the National Institute for Defense Studies (NIDS), the Japanese Ministry of Defense, or the Japanese government.

2. M. Taylor Fravel "China's Strategy in the South China Sea," Contemporary Southeast Asia, Vol. 33, No. 3, 2011, pp. 292-319; M. Taylor Fravel, "Maritime Security in the South China Sea and Competition over Maritime Rights," in Patrick M. Cronin, Robert D. Kaplan, and Will Rogers (eds), Cooperation from Strength: The United States, China and the South China Sea, Washington D.C., Center for New American Security, 9 January 2012, www.cnas.org/publications/reports/cooperation-from-strength-the-united-states-china-and-the-south-china-sea\#.V7KDmMd8OUc (accessed on 16 August 2016)

3. Linda Jakobson, "China's Unpredictable Maritime Security Actors," Sydney, Lowy Institute for International Policy, December 2014, www.lowyinstitute.org/files/chinas-unpredictable-maritimesecurity-actors_3.pdf (accessed on 16 August 2016). For similar views, see Lyle Goldstein, "Five Dragons Stirring Up the Sea: Challenge and Opportunity in China's Improving Maritime Enforcement Capabilities," China Maritime Study, No. 5, April 2010, https://www.usnwc.edu/Research— -Gaming/China-Maritime-Studies-Institute/Publications/documents/CMSI_No5_web1.pdf (accessed on 16 August 2016); International Crisis Group, "Stirring Up the South China Sea (I)," Asia Report, No. 223, 23 April 2012, https:/www.crisisgroup.org/asia/south-east-asia/southchina-sea/stirring-south-china-sea-i (accessed on 16 August 2016).

4. Bonnie Glaser, "China's Maritime Actors: Coordinated and Directed from the Top," AMTI Brief, Asia Maritime Transparency Initiative, 14 January 2015, http://amti.csis.org/chinas-maritime-actorscoordinated-and-directed-from-the-top (accessed on 15 February 2016). For similar views, see Phillip C. Saunders, "China's Juggling Act: Balancing Stability and Territorial Claims," CSIS Pac Net, No. 33, 29 April 2014, https://csis-prod.s3.amazonaws.com/s3fs-public/legacy_files/files/publication/Pac1433.pdf (accessed on 16 August 2016); Patrick M. Cronin et al., "Tailored Coercion: Competition and Risk in Maritime Asia," Washington D.C., Center for a New American Security, March 2014, www.cnas.org/sites/default/files/publications-pdf/CNAS_TailoredCoercion_report .pdf (accessed on 16 August 2016).

5. Kenneth G. Lieberthal and Michel Oksenberg, Policy Making in China: Leaders, Structures, and Processes, Princeton, New Jersey, Princeton University Press, 1988; Kenneth G. Lieberthal, "Introduction: The 'Fragmented Authoritarianism' Model and Its Limitations," in Kenneth G. Lieberthal and David M. Lampton, (eds), Bureaucracy, Politics, and Decision Making in Post-Mao China, Berkeley and Los Angeles, CA, University of California Press, 1992, pp. 1-30. 
There is wide consensus among scholars about the complex nature of the Chinese political system, but sometimes researchers differ on which aspect they emphasise.

The first view puts an emphasis on fragmentation. Since the system is fragmented, it will be difficult for the central leadership to control all actions of the agencies. As a result, coordination among China's agencies tends to be poor. ${ }^{(6)}$ The second view stresses that even though China looks different from its Maoist past, "democratic centralism," an organisational principle of the CCP, has not essentially changed, and China therefore somehow maintains coherence on important policy issues. ${ }^{(7)}$ This paper adds insight to this debate.

Here we face at least two analytical problems: lack of information and the complex nature of China's strategy. It is not easy to know the consequence of poor coordination or observe the causal relationship between poor coordination and a particular behaviour. Moreover, China's strategy tends to be expressed in vague ways and sometimes contains contradictory elements, as a result of which it is very difficult to obtain information that ascertains which action by an agency truly deviates from national policy and which does not.

There is no easy way to overcome these analytical problems, but the paper will focus on Xi Jinping's power consolidation and institutional reforms that imply greater coordination, as well as the actual behaviour of maritime actors that indicate cooperation among actors. Each type of evidence is partial, but when combined this evidence strongly suggests the development of deeper coordination among maritime actors.

The first section summarises the maritime actors that this paper deals with, including the State Oceanic Administration/China Coast Guard, local governments, the China National Offshore Oil Corporation (CNOOC), Maritime Militia (Haishang minbing 海上民兵), and PLA Navy (PLAN). These actors have their own institutional history, interests, and characteristics. The second section will analyse efforts to improve coordination under Xi Jinping: power consolidation and his personal initiative, institutional reform, and inter-agency relations.

The last two sections present two detailed case studies: the oil rig incident that occurred in 2014 near the Paracel Islands, and island reclamation works that China is currently conducting in the Spratly Islands.

\section{China's main maritime actors}

China's political system has many organisations related to the maritime domain, and each of them is under a different chain of command. Coordination between these organisations is sometimes poor, given the lack of close coordination among the chains of command.

\section{Maritime law enforcement agencies}

Before 2013, there were five civilian law enforcement agencies under independent chains of command, including: China Marine Surveillance (CMS) (Zhongguo haijian 中国海监) under the State Oceanic Administration (SOA) (Guojia haiyangju 国家海洋局) of the Ministry of Land and Resources; the Fishery Law Enforcement Command (FLEC) (Zhongguo yuzheng 中国渔政) of the Ministry of Agriculture; the China Maritime Police (Zhongguo haijing 中国海 警) under the Border Control Department of the Ministry of Public Security; the Maritime Safety Administration (MSA) (Haishiju 海事局) of the Ministry of Transport; and the General Administration of Customs (Haiguan zongshu 海 关总署). Among them, the CMS and FLEC were especially active in China's law enforcement activities and became the vanguard of China's sovereignty claims.

\section{Local governments}

Local governments, including the provincial and prefectural levels, are the primary implementers of general administration in the SCS. First, provincial governments, including those of Hainan, Guangdong, and Guangxi, have direct responsibility over managing administrative and economic activities in the SCS. Hainan Province in particular administers all of the nation's land and sea claims in the SCS. These activities include law-enforcement, constructing infrastructure, logistics, organising maritime militia, and so on.

Second, in 2012, Beijing established Sansha City (Sansha shi 三沙市), a prefectural-level city in Hainan Province located on Woody Island, part of the Paracels. Sansha City is in charge of administering all SCS features, implying Beijing's intention to enhance actual control over disputed islands and shoals. We will explore this issue later.

\section{Maritime Militia}

In China, the militia are under the dual command of the State Council and Central Military Commission. In coastal areas, the local governments and military have established a Maritime Militia. The Maritime Militia is a dualhatted force of specially registered fishing vessels with crews of fishermensoldiers. ${ }^{(8)}$ The PLA General Staff Department's mobilisation department oversees and formulates regulations for nationwide militia work. At the levels of provincial military districts and sub-districts, militia are organised and trained under the People's Armed Forces Departments of local governments. The National Defence Mobilisation Committee coordinates local governments and the military. The mission of the Maritime Militia includes military logistical support, reconnaissance, and participation in combat.

\section{CNOOC}

The China National Offshore Oil Corporation (CNOOC), one of the 116 centrally-controlled state-owned enterprises under the State-Owned Assets Supervision and Administration Commission of the State Council, was incorporated on 15 February 1982. The CNOOC is responsible for the exploration and development of Chinese offshore oil and gas resources. The top executives of the $\mathrm{CNOOC}$ are appointed by the CCP, so the Party maintains tight control over the CNOOC. ${ }^{(9)}$

6. Linda Jakobson and Dean Knox, "New Foreign Policy Actors in China," SIPRI Policy Paper, No. 26, 2010, http://books.sipri.org/files/PP/SIPRIPP26.pdf (accessed on 16 August 2016); Linda Jakobson, "Domestic Actors and the Fragmentation of China's Foreign Policy," in Robert S. Ross and Jo Inge Bekkevold (eds), China in the Era of Xi Jinping: Domestic and Foreign Policy Challenges, Washington, D.C., Georgetown University Press, 2016, pp. 137-164. For civil-military gap, see Andrew Scobell, "Is There a Civil-Military Gap in China's Peaceful Rise?", Parameters, Summer 2009, pp. 4-22, http://strategicstudiesinstitute.army.mil/pubs/parameters/Articles/09summer/scobell.pdf (accessed on 16 August 2016)

7. M. Taylor Fravel, "The PLA and National Security Decision-making: Insights from China's Territorial and Maritime Disputes," in Phillip C. Saunders and Andrew Scobell (eds), PLA Influence on China's National Security Policymaking, Stanford, CA, Stanford University Press, 2015, pp. 249-273; Harry Harding, Organizing China, Stanford, CA, Stanford University Press, 1981; Jean-Pierre Cabestan, "China's Foreign and Security Policy Decision-Making under Hu Jintao," Journal of Current Chinese Affairs, No. 2009/3, pp. 63-97, http://journals.sub.uni-hamburg.de/giga/jcca/article/view/61/61 (accessed on 16 August 2016)

8. Andrew S. Erickson and Conor M. Kennedy, "China's Island Builders:The People's War at Sea," Foreign Affairs Snapshot, 9 April 2015, https://www.foreignaffairs.com/articles/east-asia/2015-0409/china-s-island-builders (accessed on 10 February 2016).

9. Duanjie Chen, "China's State-Owned Enterprises: How Much Do We Know? From CNOOC to Its Siblings," The School of Public Policy Research Papers, Vol. 6, No. 19, June 2013, www.eisourcebook.org/cms/July\%202013/China, \%20CNOOC\%20\&\%20other\%20Stateowned\%20Firms,\%20How\%20Much\%20Do\%20We\%20Know.pdf (accessed on 16 August 2016). 
The CNOOC has long had the ambition of expanding oil-exploration activities in the SCS. The CNOOC advocates a "Second Leap Forward Program" for developing the maritime oil industry. ${ }^{(10)}$ In 2011, the CNOOC Party group (dangzu 党组), the Party cell in the company that is the de facto supreme decision-making body, promulgated "Guidelines for the Second Leap Forward Program (2011-2030)," which outlined steps to develop the company. According to the program, the first step (2011-2020) involves the CNOOC becoming a first-rate international energy company, while the second step (2021-2030) sets the goal of the CNOOC becoming a comprehensive global company with soft power. In this context, the CNOOC seeks to increase offshore production with an emphasis on the deep waters of the SCS.

Technological advances have expanded the CNOOC's ability to exploit offshore resources. The $\mathrm{CNOOC}$ has invested large amounts of money in building its own deep-water drilling capabilities. Its latest platform, HYSY981, can operate in depths of up to 3,000 meters. The project was started in 2006 as part of the 863 Program (China's high-tech state-led development plan). The platform has multiple functions, including exploration, digging, and mending wells, and is equipped with the DP-3 dynamic positioning system and a satellite navigation system. ${ }^{(11)}$

\section{PLA Navy}

The situation in the SCS is not fully militarised yet, given that the PLAN has not engaged in direct confrontation with others, but it has supported other organisations' activities in the SCS in various ways. As China's 2012 Defence White Paper noted, "The PLAN provides security support for China's maritime law enforcement, fisheries, and oil and gas exploitation. It has established mechanisms to coordinate and cooperate with law-enforcement organs of marine surveillance and fishery administration, as well as a joint military-police-civilian defence mechanism." (12)

According to Christopher Yung, the PLAN has formed a "Naval lobby" to advocate for a more proactive maritime policy, and is often very effective in coalition building. As an effective bureaucratic player, the PLAN has substantial if not decisive influence on national policy-making. ${ }^{(13)}$

A report by the National Institute for Defense Studies (based in Tokyo) stated that the PLA has become especially proactive regarding the drafting of legislation relating to the seas. The report shows that since around 2000, PLA delegates in the NPC have been calling for policy priority to be assigned to maritime issues by submitting proposals and suggestions to the NPC. ${ }^{(14)}$

\section{Cooperation between maritime actors}

\section{The Xi Jinping factor}

Xi Jinping's power consolidation has contributed to improving coordinated decision-making on maritime issues. After Xi Jinping took office in 2012, he quickly consolidated power through an anti-corruption campaign, arguably establishing the highest authority since Mao Zedong. ${ }^{(15)}$

In China's political system, the supreme leader has a preeminent role in foreign and security policy decision-making processes due to the "three-inone" principle. ${ }^{(16)}$ Since 1989, the CCP general secretary has also held the positions of Central Military Commission chairman and PRC president.

Xi's policy on maritime territorial disputes and emphasis on maritime power are factors that have facilitated China's more "assertive" foreign policy since around 2009. At the 18th Congress of the CCP in November 2012,
$\mathrm{Hu}$ Jintao read out the work report that outlined the overall direction of policies for the next generation of leaders. Xi participated in drafting the report. The work report stated, "We should enhance our capacity for exploiting marine resources, develop the marine economy, protect the marine ecological environment, resolutely safeguard China's maritime rights and interests, and build China into a maritime power." (17) The sentence clearly indicates the increased importance the Party places on maritime issues. At the $8^{\text {th }}$ Politburo study session in August 2014, Xi called for efforts to learn more about and further manage maritime development. ${ }^{(18)}$

\section{Institutional reforms}

As maritime territorial disputes are becoming a top agenda item, the CCP is making an effort to improve the decision-making structure and cooperation among agencies. Especially since becoming general secretary of the CCP, Xi Jinping has emphasised top-down decision-making and the importance of the maritime domain, and this has contributed to more centralised decision-making on maritime issues through the creation of the Central Maritime Rights Protection Leading Small Group, the establishment of the National Security Commission, the endorsement of defence and military reform, and the consolidation of maritime law enforcement agencies.

\section{Creating the Central Maritime Rights Protection Leading Small Group} (lingdao xiaozu 领导小组)

The CCP Politburo and its Standing Committee have advisory bodies known as "leading small groups." (19) The groups seem to be under the direct control of the Central Committee of the CCP, and the members are selected

10. For details on the Second Leap Program, see Wang Yilin, "Tuijin erci kuayue shixian kexue fazhan" (Promoting the Second Great Leap Forward to achieve scientific development), Qiushi (Seeking Truth), No. 9, May 2012.

11. "Daisuishin kaihatsu ni idomu Chugoku" (China seeking bids for deep water exploration), Japan Petroleum Energy Center Report, December 11, 2013.

12. Information Office of the State Council, "The Diversified Employment of China's Armed Forces," 16 April 2013, www.nti.org/media/pdfs/China_Defense_White_Paper_2013.pdf (accessed on 16 August 2016).

13. Christopher D. Yung, "The PLA Navy Lobby and Its Influence over China's Maritime Sovereignty Policies," in Phillip C. Saunders and Andrew Scobell (eds), op. cit., pp. 274-299.

14. The National Institute for Defense Studies, NIDS China Security Report 2012, Tokyo, the National Institute for Defense Studies, 2012, pp. 42-45, www.nids.go.jp/publication/chinareport/pdf/ china_report_EN_web_2012_A01.pdf (accessed on 16 August 2016).

15. Bo Zhiyue, "China's Xi Jinping Era Has Begun," The Diplomat, 6 October 2015, http://thediplomat.com/2015/10/chinas-xi-jinping-era-has-begun (accessed on 20 January 2016).

16. Jean-Pierre Cabestan, "China's Foreign and Security Policy Decision-Making under Hu Jintao," art. cit.

17. "Jianding buwei yanzhe zhongguo tese shehuizhuyi daolu qianjin: wei quanmian jiancheng xiaokang shehui er fendou" (Firmly march on the path of socialism with Chinese characteristics in order to build a moderately prosperous society in all respects), Renmin ribao (People's Daily), 18 November 2012, http://paper.people.com.cn/rmrb/html/2012-11/18/nw.D110000renmrb _20121118_3-01.htm (accessed on 18 August 2016).

18. "Xi Jinping zai zhonggong zhongyang zhengzhiju dibaci jiti xuexi shi qiangdiao: jinyibu guanxin haiyang renshi haiyang jinglüe haiyang tuidong haiyang qiangguo jianshe buduan qude xin chengjiu" (At the eighth collective study session of the CCP Politburo, Xi Jinping emphasised further focusing on understanding the ocean, marine economic strategy, promotion of the ocean, and ceaselessly gaining new achievements in the construction of maritime power), Renmin ribao (People's Daily), 1 August 2013, http://paper.people.com.cn/rmrb/html/2013-08/01/nw.D110000 renmrb_20130801_2-01.htm (accessed on 18 August 2016).

19. For leading small groups, see Lai Jingping, Dangdai Zhongguo lingdao xiaozu zhidu bianqian yu xiandai guojia chengzhang (Transition of contemporary China's leading small group system and the growing contemporary state), Nanjing, Jiangsu renmin chubanshe (Jiangsu People's Publishing House), 2015; Alice Miller, "The CCP Central Committee's Leading Small Groups," China Leadership Monitor, No. 26, 2008, www.hoover.org/sites/default/files/uploads/documents/CLM26AM.pdf (accessed on 16 August 2016); Alice Miller, "More Already on the Central Committee's Leading Small Groups," China Leadership Monitor, No. 44, 2014, www.hoover.org/sites/default/files/research/docs/clm44am.pdf (accessed on 16 August 2016). 
from relevant sections of the Party, the government, and the PLA, depending on the issues a group is responsible for. Their concrete responsibilities are considered to be providing information and recommendations, and coordination, formation, and supervision of policies. ${ }^{(20)}$ The Central Maritime Rights Protection Leading Small Group, headed by Xi Jinping, was formed in 2012. The functions of the group are: 1) to formulate strategies to advance China's maritime rights and interests; 2) to coordinate policy among numerous state entities in charge of maritime affairs; and 3) to manage growing conflict with other countries over disputed maritime territories. (21)

Establishing the National Security Commission (Zhongyang guojia anquan weiyuanhui 中央国家安全委员会)

The National Security Commission was established at the Third Plenary Session of the 18th Central Committee in November 2013. According to a communiqué issued after the session, the purpose of this committee is to improve China's national security system and strategy to safeguard the country. ${ }^{(22)}$ General Secretary Xi Jinping stated that China had to establish a powerful agency to consolidate and control all national security activities in the relentless foreign and domestic security environment. He then explained that this would strengthen centralised and unified leadership in the national security field and that it was an urgent business. ${ }^{233}$

\section{Endorsing defence and military reform}

$X i$ linping embarked on the largest military reform plan since the establishment of the PRC, significantly enhancing Xi's authority over the military. In November 2013, Xi announced a comprehensive reform plan that included defence and military reform. ${ }^{(24)}$ After two years of preparation, $\mathrm{Xi}$ announced an overall military reform plan that included cuts of 300,000 troops, the creation of a Ground Force Headquarters, Rocket Force, and Strategic Support Troops, transformation of seven military regions into five theatre commands, and the abolishment of four General Departments. (25)

The aims of the reform are to turn the PLA into a more effective fighting force and to enhance political control over the military. In order to do so, Xi has tried to concentrate power in his own hands. In January 2016, the four General Departments were abolished, and their functions were divided among 15 functional departments within the Central Military Commission. As chairman of the Central Military Commission, Xi holds more power over the PLA than his predecessors. Moreover, Xi now bears the title of "Commander-in-Chief of the military's Joint Operations Command Centre," which implies that he has operational authority over the PLA. ${ }^{(26)}$

\section{Consolidation of maritime law enforcement agencies}

The Chinese government announced at the National People's Congress (NPC) in March 2013 that it would establish the State Oceanic Commission as the high-level coordination body and a renewed SOA consolidating the organisations and responsibilities of the previous CMS, Maritime Police, FLEC, and General Administration of Customs. The responsibility, organisation, and formation of the new SOA were announced in June 2013, and the department of China Coast Guard (CCG) (Zhongguo haijingju 中国海警局) was established within the SOA. The newly established department of the CCG as the headquarters of the CCG and the CCG Command Centre is in charge of drafting systems and measures for the enforcement of maritime law, proposing various regulations, coordinating the joint command of maritime law enforcement activities by CCG units, and training units of the CCG. The consolidation is expected to improve the effectiveness of China's law enforcement activities at sea. (27)

Still, there are some unclear points concerning the organisation and command structure of the new agency. First, the organisational structure of the SOA and CCG is complicated. For example, regulations for the governance of the seas and law enforcement are drafted by the SOA, and are ultimately authorised and promulgated by the Ministry of Land and Resources after examination. On the other hand, maritime law enforcement activities implemented under the name of the CCG require the operational guidance of the Ministry of Public Security, and the commander of the CCG is a former vice-minister of the Ministry of Public Security. ${ }^{(28)}$

Second, it is also unclear who actually controls the new SOA and CCG. In terms of high level decision-making, although the announcement in March 2013 stated that the State Oceanic Commission would function as the high-level coordination body, there is no evidence that the commission is active. On the operational level, at first glance, it seems that the Ministry of Public Security has the upper hand, given its responsibility to guide the operations of the CCG. However, the fact that generals from the People's Armed Police, the organisation in charge of domestic security that is under the dual command of Central Military Commission and State Council, have taken important positions in CCG may indicate that the PLA has influence over the CCG. ${ }^{(29)}$

20. Lai Jinping, Dangdai Zhongguo lingdao xiaozu zhidu bianqian yu xiandai guojia chengzhang (Transition of contemporary China's leading small group system and the growing contemporary state), op. cit., pp. 175-177.

21. Bonnie Glaser, "China's Maritime Rights Protection Leading Small Group: Shrouded in Secrecy," AMTI Brief, Asia Maritime Transparency Initiative, 11 September 2015, http://amti.csis.org/chinas-maritime-rights-protection-leading-small-group-shrouded-in-secrecy (accessed on 20 February 2015).

22. "Zhonggong zhongyang guanyu quanmian shenhua gaige ruogan zhongda wenti de jueding" (Decision of the Central Committee of the CCP on some major issues concerning comprehensively deepening reform), Renmin ribao (People's Daily), 16 November 2013, http://paper.people.com.cn/ rmrb/html/2013-11/16/nw.D110000renmrb_20131116_2-01.htm (accessed on 18 August 2016).

23. Xi Jinping, "Guanyu 'Zhonggong zhongyang guanyu quanmian shenhua gaige ruogan zhongda wenti de jueding' de shuoming" (Explanatory notes regarding the "Decision of the Central Committee of the CCP on some major issues concerning comprehensively deepening reform"), Renmin ribao (People's Daily), 16 November 2013, http://paper.people.com.cn/rmrb/html/2013-11/16/nw. D110000renmrb_20131116_1-01.htm (accessed on 18 August 2016).

24. "Zhonggong zhongyang guanyu quanmian shenhua gaige ruogan zhongda wenti de jueding" (Decision of the Central Committee of the CCP on some major issues concerning comprehensively deepening reform), art. cit.

25. "Zhongyang junwei guanyu shenhua guofang he jundui gaige de yijian" (The opinions of the Central Military Commission on the deepening of reform of national defence and the army), Jiefangjun bao (PLA Daily), 2 January 2016, www.81.cn/jfjbmap/content/2016-01/02/content_134004.htm (accessed on 18 August 2016); "Lujun lingdao jigou huojianjun zhanlüe zhiyuan budui chengli dahui zaijing juxing" (The inaugural conference of Ground Force governing bodies, Rocket Forces, and Strategic Support Troops was held in Beijing), Jiefangjun bao (PLA Daily), 2 January 2016, www.81.cn/jfjbmap/content/2016-01/02/content_134002.htm (accessed on 18 August 2016); "Xi Jinping zai jiejian junwei jiguan ge bumen fuze tongzhi shi qiangdiao jiang zhengzhi mou daying gao fuwu zuo biaoshuai nuli jianshe 'si tie' junwei jiguan" (At a meeting with responsible comrades of agencies and departments of the CMC, Xi Jinping stressed emphasising politics, winning wars, carrying service, leading by example, and striving for establishing sitie CMC institution), Jiefangjun bao (PLA Daily), 12 January 2016, www.81.cn/jfjbmap/content/201601/12/ content_135042.htm (accessed on 18 August 2016); "Zhongguo renmin jiefangjun zhanqu chengli dahui zai Beijing juxing" (The inaugural conference of the People's Liberation Army's Theatre Commands held in Beijing), Jiefangjun bao (PLA Daily), 2 February 2016, www.81.cn/jfjbmap/content/2016-02/02/content_866.htm (accessed on 19 August 2016).

26. "Xi Jinping zai junwei lianhe zuozhan zhihui zhongxin shicha shi qiangdiao zhuzhu gaige jiyu ruiyi kaituo chuangxin juli gongjian kenan jiakuai goujian juyou wojun tese de lianhe zuozhan zhihui tixi" (During inspection of the Joint Operations Command Centre of the CMC, Xi jinping stressed seizing opportunity for reform, striving for innovation, overcoming obstacles, and speeding up construction of a joint operations command system with the characteristics of China's military), Jiefangjun bao (PLA Daily), 21 April 2016, www.81.cn/jfjbmap/content/2016-04/21/content_ 142306.htm (accessed on 19 August 2016).

27. The National Institute for Defense Studies, NIDS China Security Report 2013, Tokyo, pp. 12-13, www.nids.go.jp/publication/chinareport/pdf/china_report_EN_web_2013_A01.pdf (accessed on 16 August 2016).

28. Ibid.

29. Linda Jakobson, "The PLA and Maritime Security Actors," in Phillip C. Saunders and Andrew Scobell (eds), PLA Influence on China's National Security Policymaking, op. cit., pp. 306-309. 


\section{Inter-agency relations}

Although organisational competition does exist, China is making an effort to improve coordination between agencies. These efforts, which include bilateral meetings and exercises, contribute to actual coordinated operations.

The PLAN and the SOA have a close relationship. For example, they reached an agreement to cooperate on research and education in 2009, and have held regular meetings since then. ${ }^{(30)}$ Moreover, the commanders of the CCG are apparently trained at the Nanjing Naval Command College. (31) The Ministry of National Defence website reported that the PLAN actively cooperates in joint rights protection activities with law enforcement bodies. (32)

Hainan Province and the SOA have also developed cooperation and exchanges. Liu Cigui 刘赐贵, director of the SOA from January 2011 to December 2014, held meetings with Hainan provincial Party secretary Luo Baoming. Liu Cigui became governor of Hainan Province in February 2015(33) in a personnel reshuffle that could contribute to further cooperation. When Liu Cigui visited the SOA and met with director Wang Hong in March 2015, they expressed their joint contribution to SCS undertakings. (34)

Cooperation between the $\mathrm{CNOOC}$ and the State Oceanic Administration also seems to be improving. In February 2014, Wang Yilin visited the SOA and met with then-director Liu Cigui, while Liu visited the CNOOC in May 2014. Liu and Wang expressed their wish for the SOA and CNOOC to COoperate in building maritime power. ${ }^{(35)}$ Wang said the $\mathrm{CNOOC}$ would reliably carry out various projects, along with the related requirements of the SOA. Deployment of China Coast Guard vessels to protect oil rigs is another instance of improved coordination.

As discussed later, it is especially important to emphasise the role of the PLA and local governments in coordinating the operations of maritime actors. Linda Jakobson notes that when the PLA takes a leading role in maritime operations, a higher level of cooperation between actors can be achieved. (36)

There are numerous examples showing that these agencies actually cooperate well in both well-planned and contingency operations. For example, in October 2012, the PLAN and CCG conducted joint exercises in the East China Sea. ${ }^{(37)}$ In addition, the Impeccable Incident in 2009 showed that the PLAN, law enforcement agencies, and Maritime Militia were highly coordinated in their actions to harass the USNS Impeccable. ${ }^{(38)}$ In 2012, China successfully seized and occupied Scarborough Shoal after a 10-week standoff with the Philippines. During the standoff, dozens of government vessels and fishing boats floated in dangerously close proximity to the reef. (39) Among these various examples, I have selected the oil rig incident in 2014 and the land reclamation in Spratly Islands, because they are landmarks in China's policy in the SCS that have led to the current level of tension.

\section{Case study l: The oil rig incident}

On 2 May 2014, the CNOOC placed the Haiyang Shiyou 981 海洋石油 981 (HYSY981) deep water semi-submersible drilling rig roughly 17 nautical miles south of Triton Island and 120 nautical miles off the coast of Vietnam. The CNOOC oil rig was accompanied by ships from the China Coast Guard, Maritime Militia, engineering experts, and PLA Navy ships. In response, Vietnam dispatched naval and coast guard vessels to the area, and Chinese and Vietnamese vessels repeatedly collided in the disputed waters. ${ }^{(40)}$ This incident was remarkable because it was the first time China drilled in the EEZ claimed by another nation without permission. (41) Although the CNOOC had originally announced that the oil rig would drill until August 15, it was withdrawn in mid-July as bad weather approached.

Three factors affecting China's move illustrate the cooperation among maritime actors under the leadership of Xi Jinping: the CNOOC's aspiration to exploit deep waters in the SCS, law enforcement agencies' push for protecting and strengthening sovereignty claims, and Xi Jinping's call for establishing China as a "major maritime power" (haiyang qiangguo 海洋强国). ${ }^{(42)}$

First, as noted in the previous section, the CNOOC has long aspired to expand oil-exploration activities in the SCS. But the CNOOC has not solely pursued its own program without regard to other actors. A 2012 International Crisis Group report stated that Chinese oil companies are hesitant to conduct expensive drilling operations near countries embroiled in territorial disputes with Beijing because, "If anything happens on the rig those countries won't help us." (43)

In 2012, CNOOC chairman Wang Yilin claimed that HYSY981 is "movable national territory" and a strategic tool to drive development of the maritime petroleum industry, which will contribute to achieving China's energy se-

30. Lü Haihua, "Zhongguo haijian xunlian jidi luohu haijun shiguan xuexiao" (Training base of China's Maritime Surveillance set up at Naval Academy), Zhongguo haijun (China's Navy), 7 December 2012, http://news.xinhuanet.com/mil/2012-12/07/c_124061173.htm (accessed on 19 August 2016).

31. "Duiwu peixun: qiang sushi su xingxiang de jin yaoshi" (Training troops: Strong talent is the golden key to shape form), Zhongguo haiyangbao (China Ocean Daily), 29 June 2012.

32. "Haijun changtaihua xunluo fugai wanli haijiang dazao yuanzhongjin, gaozhongdi, duowei kongjian de haifang tixi, wei weihu guojia haiyang quanyi he lingtu wanzheng zhengedaidan" (Navy normalised patrols covering thousands of miles of maritime boundaries to build a multidimensional maritime defence system - ready to protect national maritime rights and interests and territorial integrity), Guofangbu wang (MOD website), 21 June 2014, http://news.xinhu anet.com/politics/2014-06/21/c_126651538.htm (accessed on 20 January 2016).

33. "Liu Cigui dangxuan wei Hainan sheng shengzhang cengren guojia haiyangju juzhang" (Liu Cigui was elected governor of Hainan Province, former director of State Oceanic Administration), Renmin wang (People.com), 13 February 2015, http://politics.people.com.cn/n/2015/0213/c100126561911.html (accessed on 19 February 2016).

34. Guojia haiyangju (State Oceanic Administration), "Guojia haiyangju yu Hainansheng zhengfu zhaokai zuotanhui" (State Oceanic Administration and Hainan Provincial Government held a discussion meeting), 11 March 2015.

35. Guojia haiyangju (State Oceanic Administration), "Liu Cigui huijian Zhongguo haiyang shiyou zonggongsi dongshizhang Wang Yilin: jiaqiang shendu hezuo tuijin haiyang shiye fazhan" (Liu Cigui meets with CNOOC Chairman Wang Yilin: Strengthen and deepen cooperation and promote development of maritime industry), 11 February 2014, http://soa.gov.cn/xw/hyyw_90/201402/ t20140211_30489.html (accessed on 20 January 2016).

36. Linda Jakobson, "The PLA and Maritime Security Actors," op cit., pp. 310-316.

37. "Haijun jinri Donghai weiquan yanxi moni haijianchuan zao taguo pengzhuang" (Today Navy conducts rights protection exercise in the East China Sea, simulating collision between maritime surveillance ships and foreign vessels), The Beijing News, 19 October 2012, http://news.qq.com/ a/20121019/000125.htm (accessed on 16 August 2016).

38. National Institute for Defense Studies, NIDS China Security Report 2011, Tokyo, 2011, p. 20, www.nids.go.jp/publication/chinareport/pdf/china_report_EN_web_2011_A01.pdf (accessed on 16 August 2016).

39. National Institute for Defense Studies, NIDS China Security Report 2012, op. cit., pp.18-20.

40. For Vietnamese reactions, see Tomotaka Shoji, "Vietnam and China over the South China Sea:The Confrontation Proceeds toward New Phase," NIDS Briefing Memo, No. 189, July 2014, www.nids.go.jp/english/publication/briefing/pdf/2014/briefing_e189.pdf (accessed on 16 August 2016); "Vietnam Says its Navy Vessels Collide with Chinese Ones Close to Oil Rig in Disputed Sea," Associated Press, 7 May 2014.

41. According to Andrew Chubb, China had placed survey rigs in Vietnam's EEZ in 1997 and 2004. Andrew Chubb, "China-Vietnam Clash in the Paracels: History Still Rhyming in the Internet Era?", South China Sea Conversations blog, 7 May 2014, https://southseaconversations.wordpress.com/ 2014/05/07/china-vietnam-clash-in-the-paracels-history-still-rhyming-in-the-internet-era (accessed on 20 November 2015).

42. For more details, see Philip C. Saunders and Shinji Yamaguchi, "China's Policy on Maritime Disputes: From Passive to Proactive," in Philip C. Saunders and Andrew Scobell (eds), The PLA Steps Out: Reacting to the "Pivot" or Living the "Dream"?, Washington D.C., NDU Press, forthcoming.

43. International Crisis Group, "Stirring up the South China Sea (I)," op. cit., p. 25. 
curity, developing its maritime power strategy, and protecting sovereignty in territorial waters. ${ }^{(44)}$

Wang Yilin emphasised that Xi's remarks on major maritime power provide new opportunities, new missions, and new requirements and that the maritime oil industry should become a main force in constructing Chinese maritime power. Wang also emphasised that the $\mathrm{CNOOC}$ would enhance its deep-water strategy, arguing that "deep water is not only an important alternative area for [China's] oil and gas resources, but also a front position for protecting [China's] maritime rights." ${ }^{(45)}$

Second, there has been a strong perception among various Chinese agencies that neighbouring countries have taken advantage of China's desire to avoid conflict over disputed claims. Liu Cigui, Director of the SOA, reiterated in a speech at the Central Party School that "we are facing a severe situation in protecting maritime rights at the periphery. Generally speaking, maritime resources are deprived, maritime areas are cut gradually, islands are occupied, strategic sea lanes are threatened, and confrontations around the peripheral area are exploding." (46) An article in the SOA's official newspaper mentioned that China has concentrated its oil exploration efforts in shallow waters so far, and has not done enough exploration in deep waters in the SCS. The article argued that "some waters were explored by other neighbouring countries that are challenging our sovereignty in the territorial waters. China has consistently proposed a principle of 'shelving disputes and joint development,' (gezhi zhengyi, gongtong kaifa 搁置争议，共同开发), but some neighbouring countries have not taken it into consideration and are scrambling to take the lead in exploitation." (47) Based on such perceptions, proposals to adopt a more proactive approach have become increasingly salient.

Third, Xi Jinping has strongly endorsed deep water maritime oil-exploration in the SCS. Xi supported and ordered the CNOOC to put its oil rig in Vietnamese waters. It would certainly be wrong to assume that the CNOOC deployed HYSY981 in 2014 against the will of the Party leadership.

Given the involvement of the CCG and PLA Navy ships, Xi must have known about the decision to deploy the HYSY981. Given his leadership style and role as the head of the Central Maritime Rights Protection Leading Small Group, Xi likely made the decision to approve deployment of the rig. ${ }^{(48)}$ Erica Downs argues that China's oil companies require the permission of the Ministry of Foreign Affairs and most likely of top leaders to operate in these waters. ${ }^{(49)}$ Asahi Shimbun reported that the CNOOC obtained permission from the Party leadership to deploy the oil rig in Vietnamese waters around the beginning of 2014. ${ }^{(50)}$

\section{Case study II: Land reclamation}

Since around summer 2014, China has conducted massive scale land reclamation and installation construction at seven features in the Spratly Islands, including Johnson South Reef, Cuarteron Reef, Gaven Reef, Fiery Cross Reef, Subi Reef, Mischief Reef, and Hughes Reef.

Although there is no special rule in international law that specifically prohibits any state from undertaking reclamation at sea, and although China is never the only country conducting land reclamation in the SCS, the speed, scale, intensity, and remoteness of China's ongoing manufacturing of land and infrastructure within the SCS have no parallels in history. US Navy admiral Harry Harris commented, "China is creating a great wall of sand with dredges and bulldozers." (51)

\section{Purpose}

What is the aim of these reclamation works? There are several possible goals for the project: strengthening sovereignty claims, improving living condition of local residents, contributing to the security of international navigation, and enhancing military power projection.

First, strengthening sovereignty claims is undoubtedly a crucial factor explaining China's behaviour. It is doubtful that islands created from submerged shoals constitute a basis for sovereignty claims, as a low-tide elevation creates no territorial sea, EEZ, or continental shelf, and cannot be claimed as territory in its own right. ${ }^{(52)}$ Besides legal arguments, however, creating features in the sea contributes to an enhanced presence in the area. Although China has not admitted that the purpose of land reclamation is to strengthen sovereignty claims, China's presence in the Spratlys has been growing.

Second, China's diplomats and spokespersons have categorically asserted that the main purpose of land reclamation and installation building is for civilian use. Liu Zhenmin, Vice-Minister of Foreign Affairs, explained that the purposes of reclamation are multi-dimensional, but are mainly for civilian purposes. ${ }^{(53)}$ OuyangYujing, director-general of the Department of Boundary and Ocean Affairs of the Ministry of Foreign Affairs, also mentioned that it aimed first and foremost at improving living conditions for personnel stationed there. ${ }^{(54)}$

Third, China asserts that constructions contribute to its international responsibilities. Cui Tiankai, ambassador to the United States, told an interviewer that "the main purpose is to improve the functions of facilities there so as to provide services to ships of China, neighbouring countries and other countries that sail across the SCS. Such services will include shelter for ships, navigation aid, search and rescue, marine meteorological observation, fishery service and many others." (55)

44. "Haiyang shiyou 981 pingtai Nanhai kaizuan: baowei zhuquan he jingji kaifa bingzhong" (Offshore oil platform 981 begins drilling in South China Sea: Protecting sovereignty and economic development as equally important), Zhongguo guangbowang (China National Radio), 8 May 2012, http://finance.cnr.cn/jjpl/201205/t20120508_509571464.shtml (accessed on 18 August 2015).

45. "Wang Yilin: Haiyang shiyou gongye zhutui haiyang qiangguo jianshe" (Wang Yilin: Offshore oil industry boosts the building of a maritime power), Renmin ribao (People's Daily), 25 December 2012, http://cpc.people.com.cn/n/2012/1225/c64387-20002576.html (accessed on 19 August 2016).

46. "Liu Cigui yingyao zai zhongyang dangxiao zuo zhuanti baogao shi qiangdiao jianjue weihu woguo guanxia haiyu haiyang quanyi" (Liu Cigui invited to the Central Party School made a special speech and stressed that China has to resolutely safeguard its maritime rights and interests in the waters under its jurisdiction), Zhongguo haiyang bao (China Ocean Daily), 11 April 2014, http://soa.gov.cn/xw/hyyw_90/201404/t20140411_31174.html (accessed on 19 August 2016).

47. "Woguo haiyang nengyuan kaifa wenti yu duice" (China's offshore energy development, problem and solution), Zhongguo haiyang bao (China Ocean Daily), 25 February 2014, www.oceanol.com/redian/shiping/2014-02-25/32084.html (accessed on 19 August 2016).

48. See Linda Jakobson, "How Involved Is Xi Jinping in the Diaoyu Crisis?", The Diplomat, 8 February 2013, http://thediplomat.com/2013/02/how-involved-is-xi-jinping-in-the-diaoyu-crisis-3 (accessed on 3 February 2016).

49. Erica Downs, "Business and politics in the South China Sea: Explaining HYSY 981 's Foray into Disputed Waters," China Brief, Vol. 14, No. 12, 19 June 2014, https://www.brookings.edu/wp-content/uploads/2016/06/China-Brief_Erica-Downs.pdf (accessed on 16 August 2016).

50. "Chugoku shidobu, nensho ketsudan ka: Minami Shina Kai keneki kakutoku nerau" (Chinese leaders decided early January: Aims at maritime interests of South China Sea), Asahi Shimbun, 29 May 2014.

51. "US Admiral: China 'Creating a Great Wall of Sand' in Sea," Associated Press, 31 March 2015.

52. Gregory Polling, "The Legal Challenges of China's Island Building," AMTI Brief, Asia Maritime Transparency Initiative, 18 February 2015, http://amti.csis.org/the-legal-challenge-of-chinas-islandbuilding (accessed on 28 January 2016).

53. "Zhongguo shi Nanhai heping wending de jianding weihuzhe" (China is a staunch defender of peace and stability in the South China Sea), Xinhua, 30 May 2015.

54. Zhang Yunbi, "An Interview on China's Construction Activities on the Nansha Islands and Reefs," China Daily, 27 May 2015, www.chinadaily.com.cn/china/2015-05/27/content_20827354.htm (accessed on 16 August 2016).

55. Embassy of the People's Republic of China in the United States of America, "Keynote Speech by Ambassador Cui Tiankai at the International Conference on China-US Cooperation in Clobal Security Affairs," Washington DC, 16 April 2015, www.china-embassy.org/eng/zmgxss/ t1255681.htm (accessed on 16 August 2016) 
Last but not least, land reclamation and installation construction, especially the construction of airstrips, ports, and radar facilities, would strengthen the PLA's power projection capabilities in the SCS, which were clearly limited in the past. Massive construction of airstrips would enable the PLA Air Force (PLAAF) to take action around the Spratlys, and PLA aircraft might therefore be able to cover all of the SCS. Such expansion of activities raises arguments and concerns over the establishment of a new Air Defence Identification Zone (ADIZ) in the South China Sea. At the National People's Congress in 2014, non-military representatives proposed establishment of the SCS ADIZ, and the Ministry of Defence (MOD) did not deny this possibility. ${ }^{(56)}$

Moreover, construction of airstrips and the enhanced power projection capability of China's Air Force could have implications beyond the SCS. According to Kanwa Defence Review, the airstrips are designed to be used by the $\mathrm{H}-6 \mathrm{~K}$ bomber, a new type of $\mathrm{H}-6$ bomber equipped with a CJ-10 air-toland cruise missile with an attack range of over 2,000 km. In 2015 China conducted its first Air Force drill in the western Pacific. At that time, several $\mathrm{H}-6 \mathrm{~K}$ bombers passed through the Bashi Channel. Such activities may increase as a consequence of airstrips construction in the SCS.

\section{Decision-making and implementation}

It is still unclear when and by whom reclamation projects in the Spratlys have been decided. The Asia Maritime Transparency Initiative and other media report that it was in summer 2014 that large-scale reclamation started on some reefs. In June 2014, South China Morning Post reported that China would expand its biggest installation in the Spratly Islands into a fully-formed artificial island, complete with airstrip and seaport, and other researchers and media started to keep an eye on it. ${ }^{(57)}$ But according to IHS Jane's Defence Weekly, China's large dredger ship began to appear around the Spratlys in September 2013. ${ }^{(58)}$ According to Andrew Erickson, reclamation and construction of the Johnson South Reef probably started around 2012. ${ }^{(59)}$

Given the scale and timing of the projects, it is highly likely that Xi Jinping decided the endorsement of the projects. Kanwa Defence Review reported in 2014 that it was Xi jinping himself who approved and endorsed the reclamation. ${ }^{(60)}$ Likewise, Lee Shiyin-jow, director-general of Taiwan's National Security Bureau, stated that China's land reclamation is taking place on seven shoals, and that at least five of these have been carried out under the personal orders of Xi Jinping. ${ }^{(61)}$ It is unclear why he mentioned only five, not seven, but it is likely that $X i$ decided the project as a whole.

Although puzzling, it seems that China's land reclamation effort began around 2012, but at a scale and speed not noticeable enough for foreigners to take notice. The scale and speed has increased notably especially since 2014, probably due to strategic decisions made by Xi Jinping.

The PLA, especially the PLAN, is likely taking a central role in implementing the land reclamation program. According to media reports, in September 2014, PLA Navy Commander Wu Shengli inspected the island reclamation projects for a week. ${ }^{(62)}$ When asked about the inspection tour, an MOD spokesperson answered briefly that China's activities on the islands were "rightful." (63) In addition, PLAN vessels guarded the construction site, ${ }^{(64)}$ and a company that made 120 armoured nozzles for dredging revealed that it was the PLA that ordered the nozzles. ${ }^{65)}$

China has dispatched many engineering ships and a large amount of equipment, most notably the dredger ship Tian Jing. Tian Jing was designed by Shanghai Jiaotong University and Germany's Vosta LMG, built by China
Merchant Industry Holdings Ltd., and is now operated by CCCC Tian Jing Dredging. Construction of the ship, the biggest and the most capable dredger ship in Asia, began in April 2008 and was completed in January 2010. ${ }^{(66)}$ As noted above, Tian Jing began its operations in the Spratlys in September 2013, and has rotated among Cuarteron Reef, Johnson South Reef, Fiery Cross Reef, and Gaven Reef.

\section{Building administration of Sansha City}

The current land reclamation efforts in the Spratlys are not China's first attempt to enlarge islands; China has carried out land reclamation and port construction in the Paracels since 2012. In 2012, the SOA approved a plan by the Ocean and Fishery Agency of the Hainan provincial government to enlarge Drummond Island and construct a port on the island. ${ }^{(67)}$

Land reclamation is part of a broader effort to create Sansha City, a strategic decision by the Party. In a broader perspective, Hainan Province and Sansha City have become increasingly important because local governments are charged with establishing administrative control and improve the living condition of residents.

Other factors in building administrative control over Sansha City, including maritime law enforcement agencies, maritime militia, and surveillance networks, would contribute to enhancing China's greater control of the Paracels and Spratlys. First, the Sansha City government has become an important actor in coordinating maritime law enforcement activities. In Sansha City, "military-police-civilian coordination" (junjingmin xietiao 军警民协调) has become a key phrase. According to Xiao Jie, the Mayor of Sansha City, Sansha has set up a Military-Police-Civilian Coordination Centre, and has conducted a "Six-One Project" and a "Five-in-One-Place Project." (68) The

56. "Shaishai women de chengjidan" (Expose our score records), Renda zazhi (People's Congress Magazine), 18 April 2014.

57. "China Plans Artificial Island in Disputed Spratlys Chain in South China Sea," South China Morning Post, 7 June 2014, www.scmp.com/news/china/article/1527059/china-plans-artificial-island-disputed-spratlys-chain-south-china-sea (accessed on 16 August 2016)

58. "China Goes All Out with Major Island Building Project in Spratlys," IHS Jane's Defence Weekly, 20 June 2014, http://maritimesecurity.asia/free-2/south-china-sea-2/china-goes-all-out-withmajor-island-building-project-in-spratlys-ihs-janes-360-7 (accessed on 16 August 2016).

59. Andrew S. Erickson and Austin Strange, "Pandora's Sandbox: China's Island-Building Strategy in the South China Sea," Foreign Affairs Snapshot, 13 July 2014, https://www.foreignaffairs.com/articles/china/2014-07-13/pandoras-sandbox (accessed on 19 August 2015).

60. "Xi Jinping pizhun NanZhongguohai tianhai" (Xi Jinping ratified reclamation in the South China Sea), Kanwa fangwu pinglun (Kanwa Defence Review), Vol. 10, No. 120, 2014, p. 39.

61. "PLA Land Reclamation in South China Sea Could Threaten Taiping," Want China Times, 16 October 2014.

62. Zhonghua renmin gongheguo guofangbu (Defence Ministry of the PRC), "Zhongguo jundui jiji canyu yuanzhu Xifei guojia kangji aibola" (China's military will actively participate in supporting West African countries in resisting Ebola), 30 October 2014, www.mod.gov.cn/affair/201410/30/content_4554320_3.htm (accessed on 20 January 2016).

63. Ibid.

64. "Zhongguo zai Nansha Chiguajiao jinxing tianhai kuojian junjian weihu" (China proceeds with reclamation and expansion of Johnson South Reef in the Spratlys, Navy vessels protect), Taihai wang (Taiwan sea web), 3 May 2014, http://mil.news.sina.com.cn/2014-05-03/1248777210.html (accessed on 20 January 2016).

65. Jiangsu Pacific Rubber Co. Ltd., "Gongsi shunli wancheng Nanhai zhongyao gongcheng" (The company smoothly finished important project in South China Sea), 15 September 2014.

66. Shanghai Jiaotong University, "Shanghai Jiaoda zizhu yanfa Tianjinghao" (Shanghai Jiaotong University independently researched and developed Tian Jing), 29 September 2014; "China Goes All Out with Major Island Building Project in Spratlys," art. cit.

67. "Xisha Jinqing dao huozhun tianhai jian matou" (Drummond Island in the Paracels gets permission to reclaim and build port) Guoji jinrongbao (International Finance News), 27 April 2012, http://politics.people.com.cn/GB/1026/17759194.html (accessed on 16 August 2016)

68. "Women you xinxin weihu hao guojia haiyang liyi" (We are confident of protecting our national maritime interests), Zhongguo haiyangbao (China Ocean Daily), 16 March 2015. 
Six-One Project refers to a plan to establish six things: joint maritime defence duty room, information sharing platform, maritime law enforcement rotation plan, joint maritime law enforcement plan, gradual participation of justice in the law enforcement mechanism, and maritime militia troops. The Five-in-One-Place Project refers to the establishment of a residential committee office, maritime militia post, residential cultural centre, temporary typhoon shelter, and war time command centre on the reefs where the residential committee exists.

Xiao Jie emphasised that Sansha City basically carried out regular patrols and law enforcement in the Paracels. On 6 January 2015, Sansha City conducted a military-police-civilian maritime general law enforcement exercise. ${ }^{(69)}$ The exercise included training for inspection of foreign engineering ships and search and rescue.

Sansha has set up a General Law Enforcement Bureau that conducts integrated law enforcement activities. When the Maritime Militia discovers "illegal" activity by foreign fishing vessels, it reports it to the Sansha Garrison Command, which then identifies the location of the activity and notifies law enforcement vessels. ${ }^{(70)}$

Second, in Hainan Province, building and strengthening the Maritime Militia has become an important task for local governments. When Xi Jinping made an inspection tour of Hainan Province in April 2013, he demanded that Hainan Province fulfil four aims in the SCS entrusted to it by the Party Centre, namely protecting rights, protecting stability, preserving the maritime environment, and development (weiquan, weiwen, baohu, kaifa 维权, 维稳, 保护, 开发). ${ }^{(71)}$ Xi also met with the maritime militia of Tanmen Township and demanded that maritime militias actively collect information in the far seas and support the construction of reefs. $\left.{ }^{72}\right)$

In response to Xi's demands, Luo Baoming on August 2013 emphasised the importance of the Sansha construction and mentioned "development based on civil-military integration, realising the Party Centre's strategic intention to set up Sansha City, and fulfilling the divine mission of rights protection, maintaining stability, protecting the environment, and development." (73) The Sansha City construction has now become a highpriority project in Hainan. According to Andrew Erickson and Conor Kennedy, Sansha's first 28 infrastructure projects involved a total investment of 24 billion renminbi (US\$3.81 billion), with much more yet to come. ${ }^{(74)}$

In July 2013, Sansha City established a People's Armed Forces Department and Maritime Militia. ${ }^{(75)}$ The Sansha Maritime Militia consists of more than 215 people, and one of its major missions is collecting information, as Xi jinping required. ${ }^{(76)}$ The lower-level People's Armed Forces Department was already established at Woody Island, Crescent Group, and Qilianyu (northern part of Amphitrite Group) in the Paracels, as well as in the Spratlys by December 2014. ${ }^{(77)}$ Third, Hainan Province and Sansha City are constructing a surveillance and information network in the SCS. In July 2015, the Hainan Military District built dozens of militia outposts and created a reconnaissance-information network. ${ }^{(78)}$ Moreover, Sansha City established informatised militia outposts equipped with a radar identification and surveillance system to transmit information to the Military-Police-Civilian Coordination Centre. ${ }^{(79)}$

\section{Conclusion}

This paper shows that a long-term aspiration based on a perception of victimisation by other countries taking advantage of China's restrained foreign policy has coalesced into a more coherent plan under the strong lead- ership of Xi Jinping. Of course, as noted in the introduction, because evidence is difficult to collect, any conclusion is necessarily based on interpretation and is open to debate. Even so, the paper identifies three important developments in China's maritime policy.

First, coordination between maritime actors is improving, and this is an important trend. China's maritime actors may be in competition, but not to an extent that could disrupt China's overall strategy. At least they are working under the broad policy direction of the CCP, and it is therefore the CCP leadership that is pushing the tough policy line in the SCS. In this regard, Xi Jinping's role is important. He has chosen a tougher policy line than his predecessors and it clearly affects the behaviour of maritime actors. His consolidation of power has contributed to his enhanced role. At the same time, institutional reforms initiated under $\mathrm{Xi}$ have generated friction and passive resistance among institutions such as the CCG and PLA. For example, Linda Jakobson mentioned that the newly established CCG has not achieved real integration of law enforcement activities. ${ }^{(80)}$ It is also still unclear whether military reform has been as successfully implemented as Xi anticipated. Moreover, conventional wisdom suggests that China's politics becomes unstable around the time of the Party Congress because power struggles within the party tend to intensify as the Congress approaches. This may affect policy coordination among maritime actors.

Second, the role of the PLA is operationally salient. In both case studies, the PLA was the centre of coordination between various actors. On the other hand, it is unclear what role the PLA took in the policy decision-making process. Given Xi Jinping's consolidated power and his decision-making style, the PLA's influence should not be overestimated.

69. "Sansha juxing haishang zonghe xingzheng zhifa lianyan tisheng guangkong nengli" (Sansha conducts maritime general law enforcement exercise and raises capability to manage), Renmin wang, (People's.com), 6 January 2015, http://politics.people.com.cn/n/2015/0106/c7073126334854.html (accessed on 20 January 2016).

70. "Junmin lianfang zhushou lanse haijiang" (Military and civilians jointly defend and garrison blue water maritime frontier), Zhongguo guangbowang (China National Radio), 23 May 2013, http://china.cnr.cn/yaowen/201305/t20130523_512650453.shtml (accessed on 18 January 2016).

71. "Luo Baoming: shenru xuexi Xi Jinping tongzhi kaocha Hainan zhongyao jianghua jingshen" (Luo Baoming: Deeply study spirit of important speech of comrade Xi Jinping during inspection of Hainan Province), Renmin ribao (People's Daily), 30 August 2013.

72. "Xi Jinping: jiakuai guoji lüyoudao jianshe puxie meili Zhongguo Hainan pian" (Xi Jinping: Speed up constructing international resort island, compose beautiful China's Hainan tune), Xinhua.net, 10 April 2013, http://news.xinhuanet.com/politics/2013-04/10/c_115342563.htm (accessed on 18 January 2016)

73. "Luo Baoming: shenru xuexi Xi Jinping tongzhi kaocha Hainan zhongyao jianghua jingshen" (Luo Baoming: Deeply study spirit of important speech of comrade Xi Jinping during inspection of Hainan Province), art. cit.

74. Andrew S. Erickson and Conor Kennedy, "China's Island Builders: The People's War at Sea," art. cit.

75. Zhonghua renmin gongheguo zhongyang renmin zhengfu (Central government of the PRC), "Sanshashi juxing haishang mingbinglian shouqi yishi" (Sansha City conducted ceremony to present flag to maritime militia company), 23 July 2013, www.gov.cn/jrzg/2013-07/23/content _2453699.htm (accessed on 18 January 2016).

76. "Sansha zhengquan jianshe dashji: zujian Sansha haishang minbinglian" (Chronicle of construction of Sansha City administration: Setting up Sansha maritime militia company), Hainan ribao (Hainan Daily), 29 July 2014

77. "Nanhai sidao chengli jiceng junshi zuzhi" (Grass roots military organisation set up in South China Sea), Xinbao, 7 January 2015.

78. "Zhongguo jian Nanhai junmin qingbao wang: xiu shushizuo minbing shaosuo liaowangda" (China builds military and civil intelligence network, repairs dozens of militia posts and watch towers), Sina, 6 July 2015, http://mil.news.sina.com.cn/2015-07-06/0825834473.html (accessed on 18 January 2016).

79. "Xinxihua minbing shaosuo luohu Nanhai daojiao" (Informatised militia posts settled in the South China Sea's islands and reefs), Jiefangjun bao (PLA Daily), 30 July 2015, www.81.cn/jfjbmap/content/2015-07/30/content_118745.htm (accessed on 19 August 2016).

80. Linda Jakobson, "China's Unpredictable Maritime Security Actors," op. cit. 
Third, the mid- to long-term trend is crucial when analysing China's behaviour. In the oil rig case, the CNOOC's project to explore energy, combined with a sense of crisis on China's sovereignty claims, contributed to shaping the background for a tougher policy. In the land reclamation case, the strategic decision to establish Sansha City and local governments' efforts to materialise it contributed to the current policy, the objective of which is to enhance sovereignty claims, not only for the sake of domestic nationalism but also to diminish US influence in the region by creating a fait accompli.

I Shinji Yamaguchi is a senior research fellow at the National Institute for Defense Studies (NIDS), Tokyo.

NIDS, 5-1 Ichigayahoncho, Shinjuku-ku, Tokyo 162-8808, Japan (yamaguchi_shi@nids.go.jp).

Manuscript received on 2 March 2016. Accepted on 9 August 2016. 